\title{
HUBUNGAN PENGETAHUAN ORANG TUA TENTANG DEMAM THYPOID DENGAN KEBIASAAN JAJAN PADA SISWA SDN 3 CANDISARI GROBOGAN PURWODADI
}

\author{
Oleh : \\ Diyono $^{1}$,Ariawan Tri Susanto ${ }^{2}$, Gidheon Edhi Mukti ${ }^{3}$
}

\begin{abstract}
Introduction: Thypoid Fever is gastrointestinal infection caused by salmonella thyposa that influx into the intestine. The incidence of the disease the higher, including the students of SDN Candisari 3. Thypoid Fever can be prevented by reducing snack food habits that are less clean. Knowledge of parents about Thypoid Fever have an important role in reducing snack habits in children.

Purpose of the study: (1) determine the level of knowledge of parental descriptions of disease typhoid fever (2) find a deskription snack habits in primary school students (3) determine the relationship of the level of parental knowledge about the disease typhoid fever with habit of eating snacks in elementary school students Candisari 3 Grobogan Purwodadi. Design: Type of research a descriptive analytic study with correlation design Subjects: The study population is students and parents of students of SDN School 3 Candisari. The sample size of 60 students and parents by using quota sampling.

Results: (1) The level of parental knowledge about the disease typhoid fever were high for the value - average 23.02. The percentage level of knowledge of parents with a high category is $85 \%$, the medium category being $15 \%$, and low categories of $0 \%$. (2) The habit of eating snacks to students including low category (5.18) where the percentage of moderate category $13.33 \%, 18.33 \%$ and the most category is severe of $68.33 \%$. (3) There is no significant relationship between the level of parental knowledge about the disease typhoid fever with snack habits in students, where the results of chi square test $p=$ 0.258 .

Conclusion: The level of parental knowledge about diseases of the Thypoid Fever not have a relationship with the habit of eating snacks in elementary school.
\end{abstract}

Keywords: Thypoid Fever, Level of Knowledge, Snack Habits

\section{PENDAHULUAN}

Demam Typoid (Enteric Fever) adalah penyakit infeksi akut yang biasanya mengenai saluran pencernaan dengan gejala demam yang lebih dari satu minggu, gangguan pencernaan dan gangguan kesadaran. (Nursalam, Susilaningrum dan Utami, 2005) Menurut Curtis (2006) sebagaimana dikutip oleh Muttaqin dan Sari (2011) kuman salmonella typhi yang masuk ke dalam saluran gastrointestinal saat makan atau minum kemudian akan ditelan oleh sel - sel fagosit ketika masuk melalui mukosa dan oleh makrofak yang ada di dalam lamina propia. Sebagian salmonella typhi ada yang masuk ke usus halus mengadakan invaginasi ke jaringan limfoid usus halus (plak peyer) dan 
jaringan limpa. Salah satu faktor risiko demam typoid adalah mengkonsumsi makanan yang kurang hygienis. Demam typoid lebih sering terjadi pada anak usia sekolah. Hal ini terjadi karena sesuai tumbuh kembang anak usia sekolah biasanya suka dengan makanan yang warnanya mencolok atau menarik tanpa mempertimbangkan makanan tersebut bersih atau tidak. Makanan tersebut sering dijumpai pada jajanan yang ada di sekitar sekolah.

Kebiasaan jajan merupakan bagian yang tidak terpisahkan dari kehidupan siswa sekolah dasar. Makanan jajan yang tersedia di lingkungan sekolah sulit dikontrol akan kebersihannya, sehingga dapat merupakan risiko berbagai macam penyakit termasuk demam typoid. Sayangnya keadaan ini sering tidak diperhatikan orang tua.

Menurut informasi yang diperoleh dari Kepala Desa Candisari Kabupaten Grobogan didapatkan data di Desa Candisari Kabupaten Grobogan, anak sekolah dasar yang sudah terkena penyakit tipoid tercatat 35 orang pada bulan Desember 2013 hingga bulan Februari 2014, penyebab pasti dari masalah tersebut belum diketahui. Hasil observasi awal sebagian besar orang tua tidak peduli dengan apa yang dimakan oleh anaknya. Para orang tua tersebut tidak mengetahui bahwa makanan yang tidak bersih itu bisa menyebabkan demam typoid.

Berdasarkan latar belakang di atas, maka peneliti tertarik untuk melakukan penelitian dengan judul "Hubungan Tingkat Pengetahuan Orang Tua Tentang Demam Typoid dengan Kebiasaan Jajan Anak Sekolah Dasar Negeri 3 Candisari Grobogan Purwodadi.

\section{METODE PENELITIAN}

Penelitian ini merupakan penelitian analitik dengan desain korelasional untuk mengetahui hubungan pengetahuan orang tua tentang demam typoid sebagai variabel bebas dengan kebiasaan jajan anak sekolah dasar sebagai variabel terikat. Populasi penelitian ini adalah seluruh orang tua dari anak yang sekolah di SDN 3 Candisari Purwodadi Grobogan, yang berjumlah 75 siswa. Besar sampel 60 siswa diambil dengan quota sampling, yaitu setiap kelas peneliti tetapkan 10 siswa. Untuk mengetahui seberapa tinggi pengetahuan orang tua murid atau wali murid tentang pengetahuan demam typoid. Data yang telah terkumpul peneliti analisis menggunakan program SPSS for Windows seri 16. Batas tingkat signifikansi ( $p$ ) yang peneliti tetapkan adalah 0,05 .

\section{HASIL PENELITIAN}

Berdasarkan penelitian yang telah dilakukan mulai bulan November 2014 sampai bulan Januari 2015 didapatkan hasil sebagai berikut :

1. Pengetahuan Orang Tua Tentang Penyakit Demam Thypoid

Hasil pengukuran tingkat pengetahuan orang tua tentang penyakit thypus (tipes) tergambar pada diagram 1. di bawah ini

Diagram 1

Tingkat Pengetahuan Orang Tua Siswa di Sekolah Dasar Negeri (SDN) 3 Candisari, Purwodadi, Grobogan tahun 2015

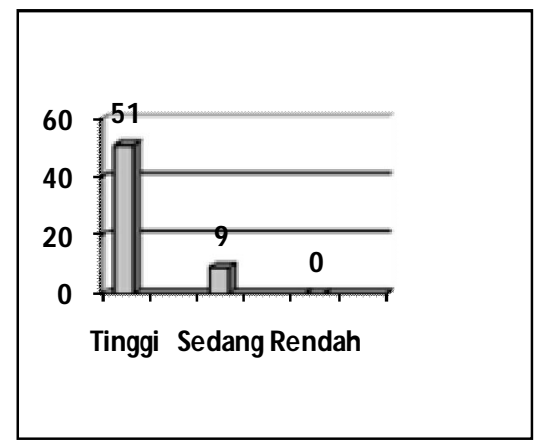


Diagram 1. menunjukkan bahwa tingkat pengetahuan orang tua siswa tentang penyakit thypus termasuk tinggi dengan nilai rata - rata 23,02. Sedangkan sebaran tingkat pengetahuan menunjukkan pengetahuan orang tua dengan kategori tinggi sejumlah 51 responden atau $85,00 \%$, kategori sedang 9 responden atau $15 \%$, dan yang termasuk kategori rendah tidak ada atau $0 \%$.

2. Kebiasaan Jajan

Kebiasaan jajan pada siswa SDN III Candisari Purwodadi paling banyak pada ketegori berat yaitu sebanyak 41 responden atau $68,33 \%$ sedangkan kelompok yang paling sedikit yaitu pada kategori ringan yaitu 8 responden atau 13,33\%. Hasil analisa univariat memperlihatkan bahwa secara umum atau rata - rata siswa mempunyai kebiasaan jajan dengan kategori berat dengan nilai 5,18. Dengan standar deviasi 1,48 menunjukkan bahwa secara umum siswa mempunyai kebiasaan jajan yang hampir sama.

Diagram 2

Tingkat Kebiasaan Jajan Siswa di Sekolah Dasar Negeri (SDN) 3 Candisari, Purwodadi, Grobogan tahun 2015

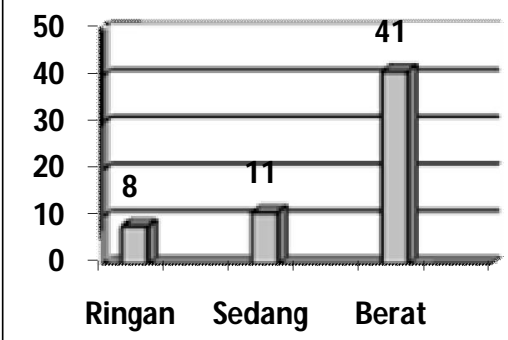

3. Hubungan Tingkat Pengetahuan Orang Tua Tentang Penyakit Thypus dengan Kebiasaan Jajan pada Siswa

Hasil analisa bivariat uji Chi Square dengan bantuan program SPSS for Windows seri 16 diperoleh hasil Sig (2-sided) sebesar 0,258. Hasil tersebut lebih besar dari 0,05 yang berarti $\mathrm{Ha}$ ditolak dengan kesimpulan tidak ada hubungan antara tingkat pengetahuan orang tua tentang penyakit thypus dengan kebiasaan jajan pada siswa SDN III Candisari Purwodadi.

\section{PEMBAHASAN}

1. Pengetahuan Orang Tua Tentang Penyakit Thypus

Pengetahuan adalah hasil 'tahu', dan ini terjadi setelah orang melakukan pengindraan terhadap suatu objek tertentu. (Notoatmodjo, 2003) Pengertian tersebut memberikan penjelasan bahwa pengetahuan seseorang tentang suatu obyek atau materi dimulai setelah individu tersebut mengenal atau tahu melalui pengindraan seperti melihat atau membaca, mendengar, atau merasakan. Dengan merasa, mendengar, atau melihat maka individu akan menjadi tahu tentang apa yang telah dilihat atau didengar.

Dewasa ini informasi tentang suatu obyek atau materi dan kejadian sangat mudah diperoleh. Kemajuan teknologi informasi seperti radio, televisi, surat kabar, bahkan secara elektronik seperti internet sangat mudah diakses, bahkan tidak hanya di perkotaan namun sampai pelosok pedesaan. Dengan kemajuan teknologi informasi tersebut maka masyarakat akan lebih mudah tahu atau mengetahui tentang 
suatu obyek atau informasi. Informasi tersebut termasuk tentang konsep penyakit. Salah satu konsep penyakit yang sudah dikenal secara umum di masyarakat adalah penyakit thypus atau dikenal dengan penyakit tipes. Hal ini sangat mungkin terjadi karena penyakit thypus merupakan penyakit infeksi yang sering terjadi di negara tropis termasuk di Indonesia dan sangat sering menyerang pada anak - anak. (Sodikin, 2011)

Kondisi tersebut terbukti pada hasil penelitian ini, dimana hasil analisis univariat menunjukkan rata - rata ibu atau orang tua siswa mempunyai tingkat pengetahuan tinggi dengan nilai rata - rata 23,02 . Selain itu dilihat dari penyebaran kategori tingkat pengetahuan juga menunjukkan bahwa secara umum orang tua sudah mempunyai pengetahuan yang cukup tentang penyakit thypus, yaitu 51 responden atau 85\% mempunyai tingkat pengetahuan yang tinggi, 9 atau $15 \%$ termasuk kategori sedang dan tidak ada yang masuk pada kategori tingkat pengetahuan yang rendah.

Faktor pendukung lain yang memungkinkan tingkat pengetahuan orang tua mengenai penyakit demam thypoid rata rata sudah tinggi adalah tingginya kasus demam thypoid di masyarakat. Hasil studi pendahuluan menunjukkan kasus warga yang mengalami penyakit thypus cukup banyak yaitu mencapai 35 warga pada periode Desember 2013 - Pebruari 2014. Keadaan yang demikian ini tentunya menjadi perhatian dan bahan pembicaraan di masyarkat termasuk orang tua siswa, sehingga sangat mungkin orang tua akan berusaha untuk mencari informasi tentang penyakit thypus. Di sisi lain penyakit thypus juga merupakan penyakit yang sangat sering dibahas di kalangan masyarakat. Kondisi tersebut sangat mendukung hasil penelitian ini dimana orang tua siswa sudah mempunyai pengetahuan yang tinggi tentang penyakit thypus atau demam thypoid.

2. Kebiasaan Siswa Jajan Kata "jajan" merupakan kata yang sangat familier di lingkungan siswa sekolah dasar. Menurut Qatrunnada (2008) biasanya anak sekolah dasar mempunyai kebiasaan membeli atau jajan makanan di kantin atau warung di sekitar sekolah dan makanan cepat saji ( fast food ). Hasil penelitian menunjukkan bahwa 41 responden atau 68\% siswa SDN 3 Candisari, Purwodadi, Grobogan mempunyai kebiasaan jajan dengan kategori berat sebanyak 11 responden atau $18,33 \%$ kategori sedang, dan 8 responden atau 13,33\% termasuk kategori ringan. Hasil perbandingan kebiasaan jajan untuk masing - masing kelas bahkan menunjukkan hasil yang sangat mencolok, dimana untuk kelas 3 dan kelas 5 semua responden atau $100 \%$ siswa mempunyai kebiasaan jajan dengan kategori berat yaitu lebih dari 6 kali seminggu atau setiap hari.

Temuan tersebut sesuai dengan konsep yang dikemukakan oleh Muttaqin dan Sari (2005) dimana anak usia sekolah seringkali tidak suka sarapan pagi secara tepat dan teratur sehingga lebih suka membeli atau jajan makanan atau minuman di sekolah. Makanan dan minuman yang dijajakan oleh pedagang di sekitar sekolah biasanya mempunyai karakterisitik warna yang mencolok dan cerah sehingga 
sangat menarik bagi siswa. Dengan tahap tumbuh kembang anak yang cenderung menyukai hal - hal baru dan menarik di sekitarnya, maka tidak mengherankan kalau siswa sekolah dasar lebih suka membeli jajanan di sekolah daripada makan makanan di rumah. Secara jelas hal ini juga dikemukakan oleh Nursalam, Susilaningrum dan Utami (2005), yang menjelaskan bahwa anak usia sekolah termasuk tahap perkembangan mental yang rumit karena anak akan lebih mudah tertarik ke hal - hal atau obyek yang baru, mulai mengembangkan hubungan sosial yang lebih luas, sehingga jika tidak terkontrol dengan baik maka anak akan lebih mudah percaya kepada orang lain seperti teman, guru, orang di sekitar sekolah daripada orang tua. Ciri tahapan perkembangan tersebut memungkinkan anak akan lebih menyukai makanan atau minuman yang dikemas sangat menarik baik dalam warna maupun rasa yang dijajakan oleh orang lain atau bukan orang tua dari siswa tersebut.

3. Hubungan Pengetahuan Orang Tua Tentang Penyakit Demam Thypoid dengan Kebiasaan Siswa Jajan

Hasil analisa bivariat dengan uji Chi Square diperoleh nilai $p=$ 0,258 . Nilai tersebut lebih besar dari 0,05 sehingga dapat disimpulkan tidak terdapat hubungan yang signifikan antara pengetahuan orang tua tentang penyakit demam thypoid dengan kebiasaan jajan pada siswa SDN 3 Candisari, Grobogan. Hasil tersebut berbeda dengan hasil penelitian terdahulu yang dilakukan oleh Putra (2012), dimana pada penelitian tersebut menyimpulkan bahwa ada hubungan antara pengetahuan ibu tentang demam thypoid dengan kebiasaan jajan pada siswa Sekolah Dasar Kedungmundu. Hasil penelitian ini juga berbeda dengan penelitian dari Sarimin tahun 2014, dimana pada penelitian tersebut diperoleh kesimpulan ada hubungan antara pengetahuan ibu tentang penyakit demam thypoid dengan kebiasaan jajan pada anak di wilayah kerja Rumah Sakit Umum Daerah Mala Kepulauan Talaud.

Berdasar analisa peneliti, ada beberapa faktor yang membedakan hasil penelitian ini dengan penelitian terdahulu, diantaranya adalah faktor keunikan dari masing - masing individu sebagai subyek penelitian. Setiap individu baik anak ataupun orang tua mempunyai keunikan yang berbeda - beda antara satu wilayah dengan wilayah yang lain. Kultur budaya dan nilai dari masyarakat pada tiap daerah tidaklah sama. Kondisi inilah yang memungkinkan walaupun secara konsep atau pengetahuan orang tua tentang suatu penyakit dalam hal ini penyakit thypus sudah sangat baik atau tinggi, namun tidak dapat menjamin anak tidak mempunyai kebiasaan jajan. Secara konsep orang tua yang mempunyai pengetahuan yang tinggi tentang suatu penyakit, semestinya mampu mengontrol dan mengatur bahkan melarang anak untuk tidak melakukan kebiasaan yang dapat menjadi faktor penyebab dari penyakit tersebut. Menurut Curtis (2006) sebagaimana dikutip oleh Muttaqin dan Sari, (2011) penyebab dari penyakit demam thypoid adalah masuknya kuman salmonella typhi ke saluran gastrointestinal bersama makanan atau minuman sehingga menginfeksi usus halus. Kondisi 
tersebut banyak ditemukan pada saat individu mengkonsumsi makanan atau minuman yang kurang bersih. Konsep tersebut sesuai atau terbukti dari jawaban dari orang tua dimana sebagian besar yaitu $97 \%$ orang tua sudah mengetahui kalau jajan sembarangan dapat menjadi perantara tertular atau terkena penyakit demam thypoid (tipes).

Dalam penelitian ini, berdasar hasil kuesioner tentang faktor penyebab dan proses terjadinya penyakit thypus yaitu masuknya makanan yang terkontaminasi dengan bakteri, 90\% responden menjawab dengan benar. Untuk pertanyaan pada kuesioner tentang kaitan makanan dengan penyakit thypus, yaitu apakah makanan yang dihinggapi lalat dapat berisiko menularkan penyakit demam thypoid (tipes), $92 \%$ responden menjawab benar. Kemudian untuk pertanyaan apakah kualitas kebersihan makanan dan minuman adalah hal terpenting dalam pencegahan demam thypoid (tipes), 100\% responden menjawab benar. Fakta tersebut menunjukkan bahwa orang tua sudah mengetahui faktor risiko penyakit thypus. Berdasar hal tersebut semestinya orang tua akan memberikan nasihat atau larangan pada anak untuk tidak jajan di sekolah, karena kebanyakan makan di sekolah sering tidak bersih dan sering dihinggapi lalat. Namun pada kenyataannya jumlah anak yang mempunyai kebiasaan jajan masih cukup tinggi. Hal tersebut menunjukkan bahwa walaupun orang tua sudah memberikan pemahaman pada anak untuk tidak jajan, namun tidak begitu berpengaruh terhadap siswa untuk tidak jajan di sekolah.

Hasil penelitian yang mendukung kesimpulan tersebut adalah siswa dari kelompok orang tua dengan kategori pengetahuan tinggi, ternyata tetap mempunyai kebiasaan jajan mulai kategori ringan sebanyak 6 responden atau $11,8 \%$, kategori sedang 11 responden atau 21,6\%, dan bahkan yang paling besar pada kategori berat sejumlah 34 responden atau $66,7 \%$. Sedangkan siswa dari kelompok pengetahuan orang tua dengan kategori sedang, mempunyai kebiasaan jajan ringan sebanyak 2 responden atau 22,2\%, kategori sedang tidak ada atau 0\%, dan kategori berat sejumlah 7 responden atau $77,8 \%$. Data tersebut membuktikan bahwa tingkat pengetahuan orang tua tidak mempengaruhi kebiasaan jajan pada siswa SDN III Candisari, Grobogan, Purwodadi. Di sisi lain hasil penelitian ini juga menunjukkan $100 \%$ siswa mempunyai persepsi bahwa jajanan makanan dan minuman yang dijual di sekitar sekolah adalah bersih. Persepsi tersebut tentunya akan membuat anak tidak takut terkena penyakit thypus walaupun sering jajan makanan dan minuman di sekitar sekolah yang tingkat hygienis dan kebersihanya belum terjamin.

Faktor - faktor seperti tersebut di atas yaitu tumbuh kembang anak, penyajian jajanan yang menarik, persepsi anak bahwa jajanan bersih merupakan faktor yang mencetuskan, mendukung, dan menguatkan siswa tetap mempunyai kebiasaan jajan walaupun dari orang tua sudah memberikan pemahaman dan larangan untuk jajan di sekolah sesuai pengetahuan yang telah dimiliki oleh orang tua. Hal ini sesuai konsep dari Lawrence Green sebagaimana dikutip oleh Adnani (2011), bahwa perilaku individu akan terbentuk secara perlahan yang dipengaruhi oleh 
tiga hal pokok, yaitu faktor predisposisi, faktor pendukung, dan faktor penguat.

\section{KESIMPULAN}

Berdasarkan hasil dan pembahasan penelitian Hubungan Tingkat Pengetahuan Orang Tua Tentang Demam Thypoid dengan Kebiasaan Jajan pada Siswa SDN III Candisari Grobogan Purwodadi Tahun 2015, didapatkan kesimpulan tidak terdapat hubungan yang signifikan antara tingkat pengetahuan orang tua tentang penyakit demam thypoid dengan kebiasaan jajan pada siswa, dimana hasil uji Chi Square $\mathrm{p}=$ 0,258 .

\section{SARAN}

Dikarenakan pengetahuan orang tua tentang penyakit typoid tidak berhubungan secara signifikan terhadap penurunan kebiasaan jajan pada siswa, maka upaya menurunkan faktor risiko penyakit demam thypoid oleh tenaga kesehatan, akan lebih baik tidak hanya difokuskan pada peningkatan pengetahuan ibu atau orang tua saja tetapi juga pada anak atau siswa. Peningkatan kesadaran siswa untuk mengurangi kebiasaan jajan dapat langsung dilakukan ke siswa, misalnya dengan memberikan pendidikan kesehatan penyakit demam thypoid langsung kepada siswa. Selain itu instansi pendidikan (sekolah) sebaiknya upaya pencegahan terjadinya penyakit demam thypoid dapat dimulai dari siswa dan pihak sekolah, misalnya dengan perintisan program kantin bersih dan hygienis.

\section{DAFTAR PUSTAKA}

Adnani, Hariza. IImu Kesehatan Masyarakat. Cetakan I. Yogjakarta : Nuha Medika, 2011.
Anies. Pencegahan Dini Gangguan Kesehatan Berbagai Penyakit dan Gangguan Kesehatan yang Perlu Diwaspadai dan Dicegah Secara Dini. Jakarta : Gramedia, 2005.

Arifanto. Orang Tua Cermat Anak Sehat yang Wajib Diketahui Para Orang Tua Sebelum Membawa Anak ke Dokter. Jakarta: Trans Media, 2012.

Cahyono, Suharjo B. Vaksinasi Cara Ampuh Cegah Penyakit Infeksi. Yogyakarta: Kanisius, 2010.

Fajar, Ibnu, et.al., Statistika Untuk Praktisi Kesehatan. Yogyakarta: Graha IImu, 2009.

Hidayat, A. Azis Alimul. Metode Penelitian Kebidanan dan Teknik Analisis Data. Jakarta: Salemba Medika, 2009.

Riset Keperawatan dan Teknik Penulisan IImiah. Jakarta: Salemba Medika, 2008.

Mutaqin, Arif dan Kumala Sari. Gangguan Gastrointestinal Aplikasi Ashan Keperawatan Medikal Bedah. Jakarta: Salemba Medika, 2005.

Notoatmodjo, S. Pendidikan dan Perilaku Kesehatan. Cetakan III. Jakarta: Rineka Cipta, 2003.

Nursalam, Rekawati Susilaningrum, dan Sri Utami. Asuhan Keperawatan Bayi dan Anak. Untuk Perawat dan Bidan. Jakarta: Salemba Medika, 2005. 
Suyanto. Metodologi dan Aplikasi Penelitian Keperawatan. Yogyakarta: Mulia Medika, 2011.

Sodikin. Asuhan Keperawatan Anak: Gangguan Sistem Gastriointestinal dan Hepatobilier. Jakarta: Salemba Medika, 2011.

Qatrunnada, Alya. Mengenal Menu Makanan Sehat. Surakarta: Suara Media Sejahtera, 2008.

Putra, Ade. Hubungan Pengetahuan lbu Tentang Demam Thypoid Dengan Kebiasaan Jajan Anak Sekolah Dasar. 2012.

Sarimin, Sisfiani. Hubungan Pengetahuan Orang Tua Tentang Demam Typoid Dengan Kebiasaan Jajan Pada Anak. 2014.

1 Dosen AKPER Panti Kosala Surakarta

2 Mahasiswa AKPER Panti Kosala Surakarta

3 Mahasiswa AKPER Panti Kosala Surakarta 